University of Nebraska - Lincoln

DigitalCommons@University of Nebraska - Lincoln

$10-2008$

\title{
Control On Platelet Adhesion And Activation Events By Selective And Specific Binding Of Plasma Protein On Peptide-Coupled Surface
}

\author{
Anuradha Subramanian \\ Department of chemical Engineering,University of Nebraska Lincoln., asubramanian2@unl.edu \\ Sanjukta Guha-Thankruta \\ University of Nebraska - Lincoln
}

Follow this and additional works at: https://digitalcommons.unl.edu/cbmesubramanian

Part of the Chemical Engineering Commons

Subramanian, Anuradha and Guha-Thankruta, Sanjukta, "Control On Platelet Adhesion And Activation Events By Selective And Specific Binding Of Plasma Protein On Peptide-Coupled Surface" (2008).

Anuradha Subramanian Publications. 7.

https://digitalcommons.unl.edu/cbmesubramanian/7

This Article is brought to you for free and open access by the Chemical and Biomolecular Research Papers -- Faculty Authors Series at DigitalCommons@University of Nebraska - Lincoln. It has been accepted for inclusion in Anuradha Subramanian Publications by an authorized administrator of DigitalCommons@University of Nebraska - Lincoln. 
Published in Journal of Biotechnology 136, Supplement 1 (October 2008), p. S404;

Biotechnology for the Sustainability of Human Society - IBS 2008 Abstracts, 13th International

Biotechnology Symposium and Exhibition; doi 10.1016/j.jbiotec.2008.07.934

Copyright ( 2008 , published by Elsevier B.V. Used by permission.

Published online October 16, 2008.

\title{
Control on platelet adhesion and activation events by selective and specific binding of plasma protein on peptide-coupled surface
}

\author{
Anu Subramanian and Sanjukta Guha-Thankruta \\ University of Nebraska-Lincoln, Lincoln, Nebraska, USA \\ Corresponding author - asubramanian2@unl.edu
}

Implantable material surfaces suffer from unavoidable major events of blood-biomaterial interactions leading to thrombus formation and finally foreign material rejection. An albuminated surface can minimize the platelet adhesion and activation that reduces the chance of thrombus formation. The main objective of our work was to design surfaces having maximum human serum albumin (HSA) binding capacity over other plasma proteins in blood by covalently grafting custom made peptides having selectivity and specificity towards HSA. First, silicon wafer surfaces were chemically treated to generate -NH2 terminated selfassembled monolayer (SAM). SAMs were then covalently coupled with (a) peptides using 1ethyl-3-[3-dimethylaminopropyl]carbodiimide hydrochloride and $\mathrm{N}$ hydroxysulfosuccinimide cross-linkers and (b) 2,4,6-tris(dimethylaminomethyl)phenol using 1,4-butanediol diglycidyl ether cross linkers. Each modification step was characterized with ellipsometry, contact angle measurements and UV-vis spectrophotometry. Peptide- and ligand-coupled surfaces were then incubated in serum for a certain duration and adsorbed protein then subsequently eluted from the surface to evaluate protein binding properties of surfaces in terms of OD measurements at $280 \mathrm{~nm}$, SDS-PAGE and ELISA. Albuminated surfaces were finally exposed to platelet rich plasma at $37^{\circ} \mathrm{C}$ and morphology of adhered platelets was observed under SEM. An unmodified silicon wafer was considered as the negative control. Surface modification with peptides and ligand changes polar and apolar components of surfaces, which in turn affects strongly the binding characteristics of those surfaces. Peptide-coupled surfaces have more polar characteristics than other grafted surfaces and thereby HSA binding is least affected by hydrophobic interaction from surface. Peptidecoupled surfaces showed maximum binding of HSA over other modified surfaces in this study. SEM pictures have shown a decrease in platelet adhesion and activation as the polarity of surface and HSA binding capacity of surfaces increased. The results demonstrated that by controlling surface functionality and polarity, non-specific protein adsorption can be minimized and thereby platelet adhesion and activation can be reduced. 